\title{
Nor Faridah's Wanderings as Female Flâneur in The Art of Naming
}

\author{
Mohd Fadhli Shah Khaidzir ${ }^{a}$ \\ mohdfadhlishah@msu.edu.my \\ School of Education and Social Sciences, \\ Management and Science University, Malaysia \\ \& \\ Centre for Research on Language and Linguistics, \\ Universiti Kebangsaan Malaysia, Malaysia \\ Ruzy Suliza Hashim ${ }^{b}$ \\ ruzy@ukm.edu.my \\ Centre for Research on Language and Linguistics, \\ Universiti Kebangsaan Malaysia, Malaysia \\ Noraini Md. Yusof \\ animy@ukm.edu.my \\ Institute Of Malaysian And International Studies, \\ Universiti Kebangsaan Malaysia, Malaysia
}

\begin{abstract}
Travellers' enthusiasm can drive them to explore new locations, especially those that are unknown and foreign to their eyes. Nor Faridah Abdul Manaf's anthology of poetry, The Art of Naming (2006) reflects the people and locations that played a significant role in crafting her poems. Using the role of a flâneur, which is closely related to the theory of psychogeography, we investigate how Nor Faridah, as a flâneuse (a female flâneur), wanders and strolls through the places she reconnoiters, and how her mental and behavioural aspects as a human being are affected by her environment. Her poems depict a strong perception, involvement, and representation of images focused on the immediate encounter of the urban cities visited, which serve as valuable pieces of evidence flâneurs while walking. Based on the analysis, the different places visited by the poet exhibit her values of humanity including empathy, generosity and love. Thus, Nor Faridah's works illuminate the position of flâneur and flâneuse, demonstrating how spaces, contrary to what is thought to be pointless roaming, actually offer insights into understanding relationship between people and their locations. As a consequence, space and position are dialectically organised in human environmental history, since her sense of space is related to the locations she inhabits, which derive meaning from their spatial significance.
\end{abstract}

Keywords: Psychogeography; Flâneur; Flâneuse; Place; Nor Faridah Abdul Manaf

\section{INTRODUCTION}

The term flâneur is closely related to a traveller who walks to places. Hazel (2012) states that the flâneur is strongly associated with travel from early on, as the very etymology and definition of the flâneur has to do with the idea of walking and movement. Baudelaire (1867) coined the term to refer to a person who observes the city or its surrounding areas and takes a physical stroll; at the same time, the observer is perceived to have a philosophical way of thinking, seeing, and feeling about things. It is an act of "walking for walking sake without any force or instructions and spend their time observing and experiencing the wandering in the urban city

${ }^{a}$ Main author

${ }^{b}$ Corresponding author 
scape, alley ways and hidden corners and hooks, observing the immediate visuals". Thus, this article examines the portrayal of a flâneur and how the surroundings of her settings have influenced her as an individual, which are depicted in the selected English poems by Nor Faridah's The Art of Naming. The travel poems analysed in this article are the ones that Faridah has stated the place visited as reference to her poems. These references are key elements in identifying that the flâneur has experienced immediate observation towards her surrounding and setting of the places visited.

Nor Faridah is currently a Professor in the Department of English Language and Literature in the International Islamic University Malaysia. The poet was born in 1963 and received most of her academic degrees overseas including New Zealand, United Kingdom and Australia. Being a creative writer, she has won numerous awards for her contributions in the literary world which includes poetry, short stories, essays and articles. She has published two poetry books; The Art of Naming (2006) and Travel Poetry (2019). She is currently writing her first history-based fiction novel which is soon to be published.

In The Art of Naming, Nor Faridah offers an insight of a journey as a Muslim woman in life. In the introduction part of the book, Susan Sherdan (2006) describes Nor Faridah taking various personas in her poems from the perspectives as a student, a traveller and also a female Muslim. Some of her poems (including the ones in her book) were published overseas; Philippines, Hong Kong, New Zealand and her home country Malaysia. According to Nor Faridah, The Art of Naming "gave her some sense of control over how she is a Muslim woman, how she defines the world, her own world, and the world of others" $(2006, \mathrm{p}$. 1). Thus, the book's topics and themes are seen through a variety of lenses and stages in her life. They contain poetry she wrote while studying abroad and travelling the globe. The flâneur's perspective is apparent in the poetry she produces when travelling, when she experiences epiphanic moments of understanding while in unfamiliar terrain. This generates evaluable meaning, which has affected the flâneur's thinking and behaviour as shown in her poems. Poetry writing and space combine to provide insights of one's worldviews, and the discovery of new places shows how the poet invites new interpretations and meanings from her interactions with her surroundings. Thus, this article seeks to examine other advantages that travellers may get from their travels beyond bringing back keepsakes such as photos, souvenirs, and cultural experiences connected with the places visited.

\section{POSITIONING NOR FARIDAH WITHIN TRAVEL LITERATURE IN MALAYSIA}

Malaysian literature written in English contributes to the country's literary fabric. Marginalized by the language medium in which the writers chose to write and surviving on scant support and a small audience, the presence of these works makes for an interesting study of the ways in which a sectional literature addresses issues of concern to fellow Malaysians. Malaysian literature in English, as a literary tradition, is still in its infancy in terms of both existence and output. Its humble beginnings dated all the way back to the 1930s, but its path had not always been straightforward. The 1980s saw a decline in this marginal literature, but from the 1990s to the present, it has remained viable, owing to several small publishing houses that have bravely overcome obstacles and losses to contribute to Malaysia's literary scene. As Amir Muhammad (2001, p. 1) succinctly puts it, Malaysian English literature "lacks a medium for consistent exposure." Early writers such as Lloyd Fernando, KS Maniam, Wong Phui Nam wrote steadily and each one possessed a strong body of works. However, in recent years, such robustness of output has not been evident in the literary output of younger writers. Discounting diasporic Malaysian writers such as Shirley Lim, Hilary Tham, Preeta Samarasan, Tash Aw, Tan Twan Eng whose works enjoy wider reading audience and support from international publishers, local writers writing in English have very few avenues that back up their creative 
works which explains the sporadic nature of local writers who are mostly not full-time writers but write out of their love for literature. Nor Faridah, consistent with the profiles of newer Malaysian writers since 2000, does not publish regularly in English. Since she writes in both Malay and English, there have been more Malay short stories published in anthologies as well as in mainstream newspapers such as Utusan Malaysia.

There has been little study done on the Malaysian landscape in the form of travel literature. Another intermittent Malaysian writer, Rehman Rashid, wrote four books about various parts of Malaysia: A Malaysian Journey, Small Town, Pangkor: Treasure of the Straits, and Peninsula: A Story of Malaysia. A Malaysian Journey, the most famous, chronicles two journeys: a physical one undertaken by the author upon his return to Malaysia after a long sojourn abroad, and a crucial one through Malaysia's often fractious post-independence past. As a result, rather than focusing on his observations of space and time, his books have been analysed as alternate histories of Malaysian culture. Muhammad Haji Salleh, a poet who mostly writes in Malay, has a number of poems about place. In her essay on Muhammad, Noraini Md Yusof (2003) illuminates his obsessive preoccupation with self-examination and self-discovery as he journeys through new environments, projecting a redefinition of his Malay identity as he returns to his origins for cultural and psychological restoration. According to Raihanah M.M. and Vin D'Cruz (2003), Muhammad Haji Salleh's writings about the various places he has visited illustrate not just the learning about the locales but also the persona's nostalgia for the homeland as well as the insights he knows about himself and the various cultures he encounters. Ruzy Suliza Hashim and Fatin Nur Syahirah Faizal (2017) demonstrate how Nassury Ibrahim's position as a flâneur adds a new dimension in providing insights into the moods and thoughts of an urban dweller in their study of his poetry in Ruang Kota through the lens of psychogeography. The poet used to live in several areas of Kuala Lumpur, including Gombak, Petaling Jaya, Jalan Klang Lama, Pantai Dalam, Sentul, Jalan Haji Abdullah Hukum, and Bangsar. In his poetry, he emphasises both the glamorous and the ugly sides of these locations. As a result of this psychogeographic perspective, it is clear that the poet wishes for the city to embrace kampong virtues of neighbourliness and good living, and he seems to conclude that if urbanites adhere to these principles, the city will become a friendlier place to live. As a result, his choice of locations serves the purpose of reminding his viewers of their civic responsibilities as city dwellers. This brief analysis of literature highlights the gap in studies on space and place, as well as the implications associated with the authors' focus on these geographies. We hope to explore Nor Faridah's persona's mental, analytical, and spiritual relationship to the places through her poetry in order to explain how the physical path represents the struggles and reconciliations of self and those around her.

\section{FLÂNEUR AND PSYCHOGEOGRAPHY}

The word flâneur is closely related to the theory of psychogeography, since both ideas are concerned with the atmosphere and urban cityscape. This term is synonymous with flâneur in that it refers to individuals who wander and discover cities and their environs without a fixed destination, thereby evoking their experience. In the 1950s, Guy Debord coined the word "psychogeography," describing it as the study of both psychology and geography, as well as their interaction in influencing how individuals think and behave. According to Self (2007), psychogeography allows adventurers to feel a feeling of fulfilment that is otherwise inaccessible while travelling through other modes of transport. The person who walks and roams around streets while watching and paying attention to the landscape and surroundings suits the role of a flâneur, who may appear to be an onlooker who observes the city or its surroundings at random and seemingly without intent, but does so with an inquisitive wonder and an infinite capacity to absorb the city's activities. 
The role of a flâneur has always been defined using the term "he" because men are commonly seen always to roam the streets freely as compared to their female counterparts (Gleber, as cited in Dreyer \& McDowall, 2012), contends that the concept of the female flâneur was rather weak, if not absent during the time of modernity. However, there has been mention of female figures in some narratives as reported by Elkin (2017, p. 21) including a reference in Baudelaire's poem where he described a passer-by as "slender, in heavy mourning, majestic in her grandeur/A woman walked past me." This is an indication that there were female figures who were seen on the streets at the same time Baudelaire's male flâneur roamed the city. Unlike the stereotyped thinking that were associated with women on the streets. these women, however, were not prostitutes; Elkin further argues that sex-workers "were strictly controlled" and "her clothing was strictly policed" (p. 20). They did not have the luxury and privilege to wander the streets aimlessly. However, because of the restricted focus on women to roam freely in the street, there could have been limited focus on the female figure as a flâneur, a person capable of walking in the cities and interpreting the world according to her views. At the same time, Virginia Woof's essay Street Haunting brings into sharp focus the image of a flâneuse as she leisurely strolls along the streets, seeing, gazing, and contemplating; Woolf desires to claim an ungendered place in the city by walking through it. Her novels exemplify this attempt at making cityscapes spaces of women's own. Her characters integrate themselves into the world by becoming attentive to the shifts in the affective landscape. As A. Snaith and M. H. Whitworth $(2007$, p. 2) explain, "the question of women's relationship to the city, particularly its public spaces, is central to her spatial politics." Thus, as K. Dean (2018) implies, Woolf's female walkers have a strong impact on modern perceptions of women walkers who not only participate in Baudelaire's idea of the flâneur but also challenge it by suggesting that the flâneuse should not ignore the crowd but also engages with individuals. She is not required to walk alone to be a flâneuse; rather, she must subvert preconceived ideas by retaining her belief that the city is worth experiencing through its landscapes. Taking a page from Woolf's definition, a flâneur embodies the liberating and imaginative ability of women wandering freely through the streets under the watchful eyes of the patriarchy. It is more difficult for a woman to be a loafer than it is for a man; she lacks the same degree of invisibility, and for a Muslim woman, such as the persona in Nor Faridah's poetry, her attire and identity distinguish her from the crowd. Thus, her destabilising act of being a flâneuse is synonymous with reclaiming the space and her right to be in the city.

Nor Faridah is justified in our identification of her as a flâneur because she connects with her audience by providing cues that the locales she appropriates are laden with meaning. As Georges Perec (1999, p. 109) emphasises, "space is a doubt ... I have to constantly mark it, to designate it. It's never mine, never given to me, I have to conquer it," the Muslim poet, too takes possession of the places she has visited and mould them in such a way that exhibits her thinking and behaviour as a person. By identifying the different localities in her poems, she demonstrates her sensitivity towards them; her field of view creates a meaning unique to her, and that meaning can be deconstructed into an infinite number of ways by her readers. Her impressions of her environment have led to what Baudelaire referred to as an "awakening" specific revelations during which the poet's past and present converge and teach concrete lessons that live on in flâneur's life.

Lynch (1960) used a psychogeographical method to investigate the imageability or mind mapping of how individuals see their surroundings. This insight can be applied to this study, as Nor Faridah's poems depict perceptual experiences of places and document the effect of external elements such as descriptions of places, personal observations, and interactions with people, all of which are explained through a cognitive mapping of her understanding. Lynch continues, "the perception of the city is not sustained, but rather partial, fragmentary, mixed with other concerns. Nearly every sense is in operation, and the image is the composite of them 
all (1960, p. 2). Thus, Nor Faridah assumes the role of finding and interpreting her environment, as shown by her poetry, which span a range of topics, values, and insights that represent her expansive view on the locations visited.

\section{FLÂNEUR, THE SPATIAL ELEMENT, AND THE LEARNER OF PLACE}

The primary role of a flâneur is to stroll leisurely and explore the surroundings; Baudelaire describes the act as unhurried walking in order for the walker to be seen, and the feeling of roaming around the urban cityscape, alleyways, and secret corners and nooks watching the immediate can be felt more acutely. A flâneur like Nor Faridah walks to different places and explores the people and the places, and at the same time, she is affected internally and externally by her surroundings. Hence, what is portrayed by the surroundings, that seem to be a routine on a daily basis, serves as a critical component of the flâneur's view of the universe, as she picks up and analyses elements of her findings according to her own understanding.

The flâneur is a critical component of the way space is perceived. She serves as both a performer and an observer in public space, or as both, a narrator and a translator of the space she traverses. In any case, the flâneur is a result of her spatial setting, which shapes her thinking and behaviour. The themes and ideals expressed in Nor Faridah's poetry are reflections of the spaces she has encountered and how they have influenced her. According to Nuvolati (2017), a flâneur is someone who, through her literary and creative works, reimagines and values (more or less consciously) familiar spaces in novel ways through constructing unique paths, valuing marginal spaces, demystifying sacred icons, and creating provocations. Therefore, the flâneur's position is often seen as a double face; as both an object and a subject of urban geographies, it presupposes a nuanced reading with a cascade of implications for the re-symbolization of urban spaces. For a flaneur such as Nor Faridah, the documentation and interpretation of her psychogeographical experiences are accomplished via the use of her language, style of writing, and the rich imagery portrayed in her poetry.

There has been little attempt at standardizing the characteristics of a flâneur, however. Auguste de Lacroix (1984, as cited in Richard Wrigley, 2014), identified the flâneur with the focus towards his superior sense of awareness, sensibility and urbanity. These three elements differentiate a flâneur from a normal stranger lost in unfamiliar places. This is because a flâneur that possesses these three elements will be affected by their surroundings and thus, resulting in a change of thinking and behaviour. Despite Nor Faridah's absent reference to her role as a flâneur in her journey through her works. Nevertheless, she fits the description of a flâneur as described by de Lacroix as "an attentive city-dweller who willingly and often deliberately engaged in social interaction" (as cited in Richard Wrigley, 2014, p. 145). In The Art of Naming, we can see how the surroundings have affected her as an observer in places that are unfamiliar to her but have become meaningful in retrospection. Collectively, the places become a tapestry of her identity, a Muslim woman negotiating foreign spaces and claiming her right to be there.

The atmosphere of a particular location acts as a learning experience for the flâneur who makes use of the interconnected spaces brimming with cultural and educational elements. This involves spatial relationships, the ability for individual learners to travel about, and a plethora of enigmatic, rich worlds to explore (Gallagher, 2010). Ross (2009) argues that the learner's position, as opposed to that of a passive observer, shifts back and forth in terms of the spectator's involvement from necessary to unknown; from prediction to fear; and from a centralised presence to an inability to localise. The flâneur in Nor Faridah makes extensive use of her perception and understanding from her surroundings in order to promote a mechanism of learning that is connected to both her experience and immediate observation of the environment around her. In brief, she is more than a spectator in her travel poems; she assumes 
a responsibility that Gallagher (2010) describes as an object in exploratory motion, undulating between inquiry and refection, and constantly crossing boundaries. Additionally, Ross (2009) suggests that the flâneur traverses the ambiguity of arrival embodied in augmented reality by refusing to see experience superficially and actively finding new ways of thinking and understanding. Nor Faridah, in her poetry, engages in a variety of learning processes that pique her imagination about the unknown elements of various settings. Using Gallagher's (2010) parlance, she recognises the malleability of the urban cultural legacy in which they associate, as well as the fact that the environment itself is always in a state of not-knowing and construction. As a result, the flâneur encounters this state of secure not-knowing as she accepts the distinction between literal and figurative representations of the surroundings. Therefore, her poetry shows the way in which her mind moves from new to familiar settings and experience as she attempts to communicate with the environment and recast her understanding of the world through her verses.

\section{METHODOLOGY}

The two sections above describe the parameters of psychogeography. As developed by Ross (2013), literary psychogeography takes into consideration the importance of landscape setting illustrated in the fictional works. In adapting psychogeography to literary theory, Ross (2013, p. 6) emphasises that:

For this reason, psychogeography as a literary theory, though it begins in the physical environment, is not limited to the mundane, but includes the psychological, including the mind in all its creativity. The physicality of the conception of psychogeographical experience does not limit, but provides a framework, it might be said, for the subjective.

This suggests that the background for the plot is not only a backdrop for the character, but rather has an impact on the human imagination, or on a person's projecting of inner feelings or moods into the outside world, and thus does not constrain its ingenuity. It is used in this analysis to show the chosen poetry in order to determine how the landscape of the locations influences the characters' mood and behaviour. Literary psychogeography elucidates the narrative voice in fictional works in relation to the landscape setting and its impact on the human mind's growth. As highlighted by Ross (2013, p. 3):

Such writers explore the significance of geographic location, setting, and spatiality for narrative and often include the relevance of modern theories of mind and the brain, beginning with an understanding of fiction as at least partially originating in a spatially located observing consciousness, or array of consciousness, as being pertinent to theories of fiction creation.

Above all, literary psychogeography also showcases how writers manipulate place settings in order to cater to reader's imagination.

Nor Faridah's collection of poetry, The Art of Naming, is analysed in terms of how the poet depicts the locations she went or lived in via her interpretation of her thoughts and actions in order to create unforgettable memories during her trips. The eight poems chosen for this study are set in various cities around the globe, with the titles including the names of the locations and/or referencing vivid images of the locations depicted in the poems. Thus, her poems will put a greater emphasis on the thematic representation, language, style, symbol, and the rich imagery that she has effectively explored and portrayed in her poems about the places she visited. Nor Faridah's study and presentation of these elements from her own viewpoint throughout her exploration and observations demonstrates her degree of connection to the locations. Psychogeography enables us to comprehend the poet's position as flâneur on the precipice of two worlds, the physical and the emotional. 
Understanding Nor Faridah's background helps us to comprehend that the places she has visited are among those that are both familiar (revisited) or unfamiliar (first time) to her due to academic purpose and also for travelling sake. Among the places she explored were Lahore (India), Manila (Philippines), Hamilton and Auckland (New Zealand, Yokkaichi (Japan), Hanoi (Myanmar), Islamabad (Pakistan), and Arlington (United States). It is these localities that the people and its surroundings have resulted her anthology of poetry. And it is through these places that she has found values which have made an impact towards her as an individual. The places represented in the following map in figure 1 shows a mapping of various places that Nor Faridah traverses in her various journeys.

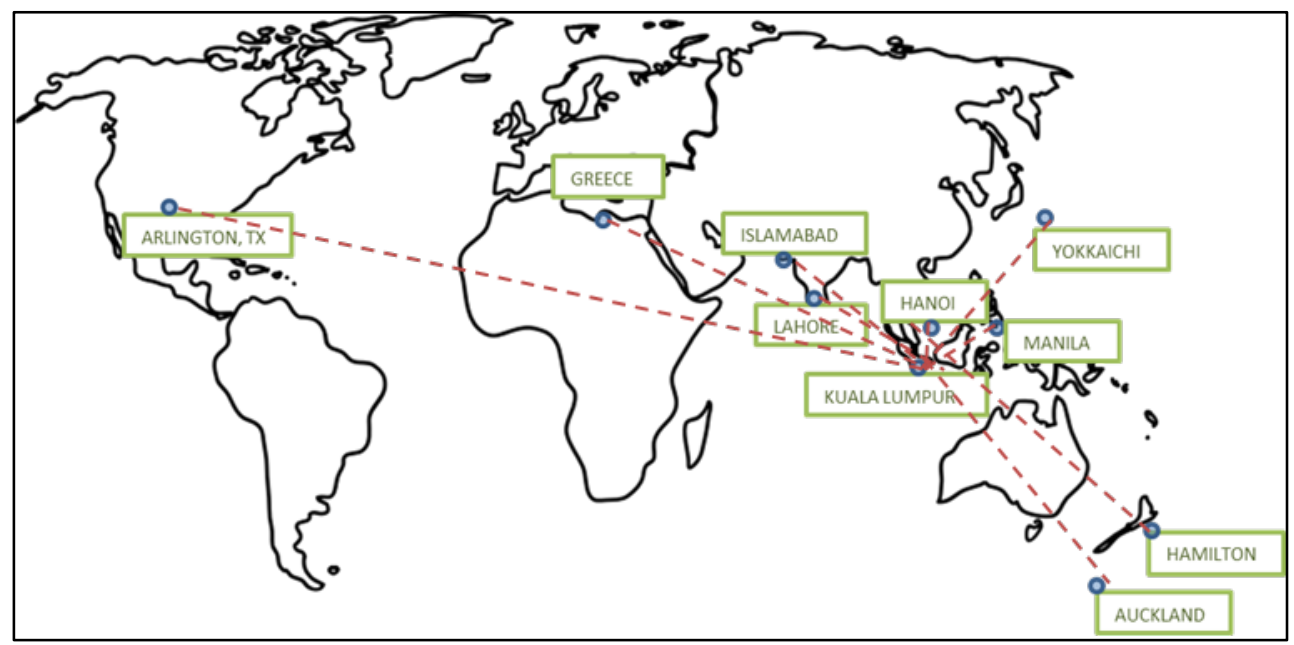

FIGURE 1. Locations

What appears interesting in the mapping of her journeys is the breadth of space covering different communities - some of them are so different from her Malaysian homeland.

\section{ANALYSIS AND DISCUSSION}

Nor Faridah's poems are divided into sections titled "Mad lady in the attic," "Farewell womanhood," "Poems of Islam and Islamicity," "Poems of people and places," and "The art of naming." Rather than pursuing the thematic thread that she has woven, this essay would focus on the representation of eight poems set in cities around the world. Some of the poems revolve around the physical experience of meandering the streets, while others are about the emotional journeys associated with recalling particular locations for specific reasons.

The first poem, "I had asked so much," demonstrates how Nor Faridah deals with her environment when attending a conference in Manila. In this instance, she strikes up a conversation with a man who happens to be another poet. She is moved by an anthology of poetry in the line..."What book with such beautiful verses", and is informed that it was composed by his daughter, another poet. Nor Faridah then bombards him with questions: 'Where is she now?'... But what did she die of?.. was it a car accident? ... cancer?," much to the chagrin of the male poet, who remains silent and shows disquiet at this invasion of his privacy. Finally, he responds... "she jumped off a bridge/That was her last poetry" (The Art of Naming, p. 18). What is highlighted here is the difference between the sociable flâneur and her reticent conference partner during a break, the brief moment when they share a moment of profound pain on the one side and an awakening to being adabless, a malay word "adab" meaning "manners" coined with suffix "less" to describe an individual lacking in social etiquette on the other. As she gains insight and knowledge about his personal pain through her 
conversation with the man, she also gains another critical lesson in the poem's final lines, in which she learns to refrain from further involvement in other people's affairs. This is shown in the line... "The silence I returned to him could never express the guilt I felt/For asking so much" (The Art of Naming, p. 18). This poem exemplifies the flâneur's freedom of observation of the cityscape and its inhabitants, but with minimal and restricted interaction with what the place has to bring in terms of various customs and cultures. Thus, as a visitor to a new place, Nor Faridah explores and analyses her experience and later accepts its complexity as a foreign individual in a new environment, as well as her position in the public and private spaces of modern Manila.

Another aspect that can be found in the poem is the representation of the self in the flâneur is shared. In the line... "the Asian in me could not be silenced" highlights to the readers the identity of the flâneur and her embedded characteristic of being Asian which was believed to be the reason why she keeps on asking questions to the Filipino poet, despite getting the silent treatment from him. This part reveals the complexity that Gallagher (2010) mentioned of layering between the process of exploration and reflection, which is a constant boundary crossing. Nor Faridah, in her attempt of understanding and interpreting the situation, might have been influenced by her own experiences, background, knowledge and style.

Nor Faridah assumes the part of a spectator in "Balancing Actions in Hanoi," in which she acknowledges the presence of another walker occupying the same room. She observes in the line... "vegetable woman/walks as if on a tight/rope" (p. 31); in contrast to the poet's leisurely stroll, the other woman walks with intent. She can see the vegetable vendor juggling her goods; she does not have time to appreciate the landscape or to watch the flâneur. Nor Faridah then speculates on another case for the Hanoi woman - that of a sex worker who relies on her body for survival. She emphasises the burden of women regardless of whether the woman being observed makes an honest living or not. This singular understanding of her observation mixes the method of the stroller's casual eyes with the detective's purposeful scrutiny. Thus, the flâneur in some sense celebrates the unmatched luxury of being both herself and someone else as she pleases. By acting as both an outsider and a member of the crowd, she is able to surmise on the rapid shifts in ethical thinking, religious standards, and sexual consciousness that occur in a city environment such as Hanoi.

Nor Faridah admits in the poem "Yokkaichi," based on her experience in that place, how she falls short of Japanese hospitality. This stands in stark contrast to mother nature's inhospitality in Japan, in the line... "this is a place where typhoons dance every year," leaving city dwellers and tourists like Nor Faridah "locked up in their homes" (p. 21). She peers out her hotel window into the unwelcoming sky, which she describes..."trees swaying [and] clouds as dark as they can be" (p. 21). Although the atmosphere is hostile, her Japanese host, who Nor Faridah refers to as "samurai men," are warm and friendly. They brave Yokkaichi's inclement weather in the hope that she has "enjoyed Japanese hospitality" (p. 21). There is a moment of revelation as she bows "knowing very well that [she] will never match/ the generosity Japan has shown [her]" (p. 21). She learns a valuable lesson in kindness and friendship through Yokkaichi, demonstrating her adaptability to new circumstances and understanding the lessons imparted between friends from two worlds. The poet also uses metaphors well in this poem. She describes how nature has some effect on the city and its inhabitants, citing how typhoons, earthquakes, and strong winds cause sufferings and destructions. Despite this annual adversity, there is an existence of a Japanese acceptance and exuberance of spirit. Within the short lines of her observation as a flâneur, Nor Faridah encounters spatial dislocation, philosophical reconfiguration, and cultural misalignment. The place, the people, and the landscape, all, have some degree of effects on her in which she experiences being "upside down"; she, too, turns 360 degrees in her assessment of herself as a Muslim woman and of her Japanese male friends whose hospitality exceeds her expectations. 
Nor Faridah's poem "Islamabad" calls into question the dignity of men and women by showcasing the presence of a female don, a rare sight in a world where women make up just $30 \%$ of the skilled workforce relative to men (The World Bank, 2016). This is because women in Pakistan do not have the same rights as men. Inquiring "how do you do it" of the female don bears a significant issue of opportunities and challenges; the addressee's response demonstrates the tribulations and heartaches as seen in... " however, we should never show them when we cry" (p. 25). The poet pits many individuals in this poem, including the female don, her male peers, the faculty junior clerk, and Nor Faridah herself. In deference, her male colleagues "shared their lunch with her", the don herself gave her food to a junior clerk, "to the least fed" (p. 25). As Nor Faridah makes her way from an official room to the junior clerk's residence, she notices how his residence is "built simply, to shelter him from rain and heat" (p. 25). Again, she reveals another awakening via a stranger she has just met; his deference gives the poet a lesson in modesty and compassion. The meaning of society is not quantifiable in terms of material goods but rather in terms of moral principles - in this case, how locals treat their own counterparts and how they treat their hosts, those regarded as outsiders. Thus, the meaning of humanity is determined by the extent to which the personality is affected by the setting's mind and behaviour, two critical components of psychogeography.

Nor Faridah encounters a Pakistani architect who confidently reveals to her "his piece of art" in another poem titled "Lahore" (p. 26). The line... "a home he built which he could adapt to heat and cold," is an energy-efficient structure that seems to be environmentally friendly. On the rooftop, however, is a garden complete with a barbeque pit, lighting, and fountain that the architect has designed to evoke memories of "Islamic gardens of the past" (p. 26). Here, we see a clash of ideals. On one hand, the house is inexpensive to maintain; on the other hand, the garden looks lofty, in need of lighting and a fountain to demonstrate a bond to Islam's history. Is Nor Faridah, a Muslim traveller who "courageously discusses what her faith in Islam means to her" (Introduction, XV), unaware of this collision of values? As Goebel (1998) explains, a flâneur often attempts to interpret life from the eyes of the indigenous and also encourages international signs to contradict her subjective preconceptions and the universalistic assertions of other beliefs. Accordingly, Nor Faridah creates meaning for the international sights as a rhetorical result to her own shortcomings through her honesty in observing and her self-aware artistic predisposition.

The poem "New Zealand Revisited" describes the flâneur's return to the country where she studied as a university student. Nor Faridah looks for icons and experiences associated with her environment and those with which she is able to identify, amid her surroundings' continuous shift. This is shown in the lines... "You have grown younger/ I expect an aging white haired woman" (p. 23). Unlike the former New Zealand, the new one is no longer a land of white people. It has developed into a " vivacious" (p. 23) and multilingual society; its diversity is astounding. Though Nor Faridah wishes to "welcome this fresh identity," she also pines nostalgically for New Zealand's former visage "for old times' sake" (p. 23). The divergence between now and then is a defining feature of the flâneur's view as she returns to familiar roads and artefacts. Separated by time - she has aged somewhat, but her memories of her youth remain fresh in her mind, and she attempts to reconcile the home she once knew and cherished with the abode that has acquired "so many faces" that it has become almost alienating.

Nor Faridah's return to Hamilton is described in the other poem, "Hamilton in the new millennium". There are two kinds of descriptions: that of the area and those of its inhabitants. The location has remained unchanged over time - "The rose garden still smells good" and "the river as tranquil as I left it," the farm, Waitomo caves, and the ice cream (p. 24) - her memory of the sound, smell and taste remain intact. However, the feelings evoked by the recollection of what Hamilton was in her youth, a place where fun and informality reigned - the "laughter and cackle has now gone" and "people dress well to enjoy their unique night out" (p. 24), those 
happy days seem to have vanished. Despite this loss, the flâneur remembers the affection of her New Zealand mates, "The Simms remain as welcoming and as friendly," their interactions are still congenial, as if the years and distance between them have not diminished the consistency of their relationship. She emphasises in the final line that "nothing has changed" (p. 24), implying that her return in the new millennium would not diminish her respect and fondness for Hamilton of the previous millennium.

Despite the fact that these two poems were composed in two distinct locations, they have one thing in common: both locations are revisited following an extended time of absence. This is because Nor Faridah earned her B.A. (Hons) in English from the University of Waikato in New Zealand. One might argue that returning to the same location would have little perspective in comparison to observing an unfamiliar location for the first time. However, the flâneur engages in two distinct modes of observation. Previously, she was an undergraduate, and upon her return, she sees the campus as an academician and adult. As a result of her matured ability to comprehend and analyse her surroundings, her epiphanic realisations manifest in a variety of forms. In line with Coverly's (2006) theory, examining contemporary modes of urban perception involves identifying novel modes of observation, vision, and knowledge. Nor Faridah, as an older adult with a family in tow, pines for the young woman she once was, and this longing is amplified when the two poems are read together as a record of the past and present.

In our final review, we will look at Nor Faridah's song "I Will Cry In Your Shadow Of Living," in which she pays homage to a close friend in Arlington who died of lung cancer. Sharing the same love for poetry, their "friendship transcends age, race, religion, place and time/ Very often it borders on sisterhood thicker than blood itself" (p. 27). This poem exemplifies the flâneur's position by retelling, recreating, recapturing, and writing it down as a result of her memories that have significant effects on her existence. She recalls her friend's kitchen, and two women demonstrate an appreciation of one another's needs inside the domestic room. The Jewish friend respects the Muslim woman's need for "halal meat," and the Muslim friend is aware of her friend's desire for "pilau rice and spiced beef" (p. 27). Outside, the freezing weather stands in stark contrasting the warmth inside the house and their friendship. Her friend extends her hospitality despite her illness. Suffering from the effects of chemotherapy and radiation, she compares her agony to "driving with no rearview mirror;" her Arlington friend is also another flâneur in her path towards death, and she cannot afford to look back. Perhaps the agony of losing her loved ones is too great to imagine, but her sense of literary aesthetics remains keen as she evaluates Nor Faridah's poetry. The final two lines of her poem..."I do not feel cancer's pain/But I can weep in the shadow of your living," demonstrate that Nor Faridah will never be a passive spectator, meandering aimlessly and quietly through the city and its environs. Instead, the flâneur is a self-aware observer who challenges and connects her acquired experience and is influenced by her surroundings, which shape her mind and actions. 


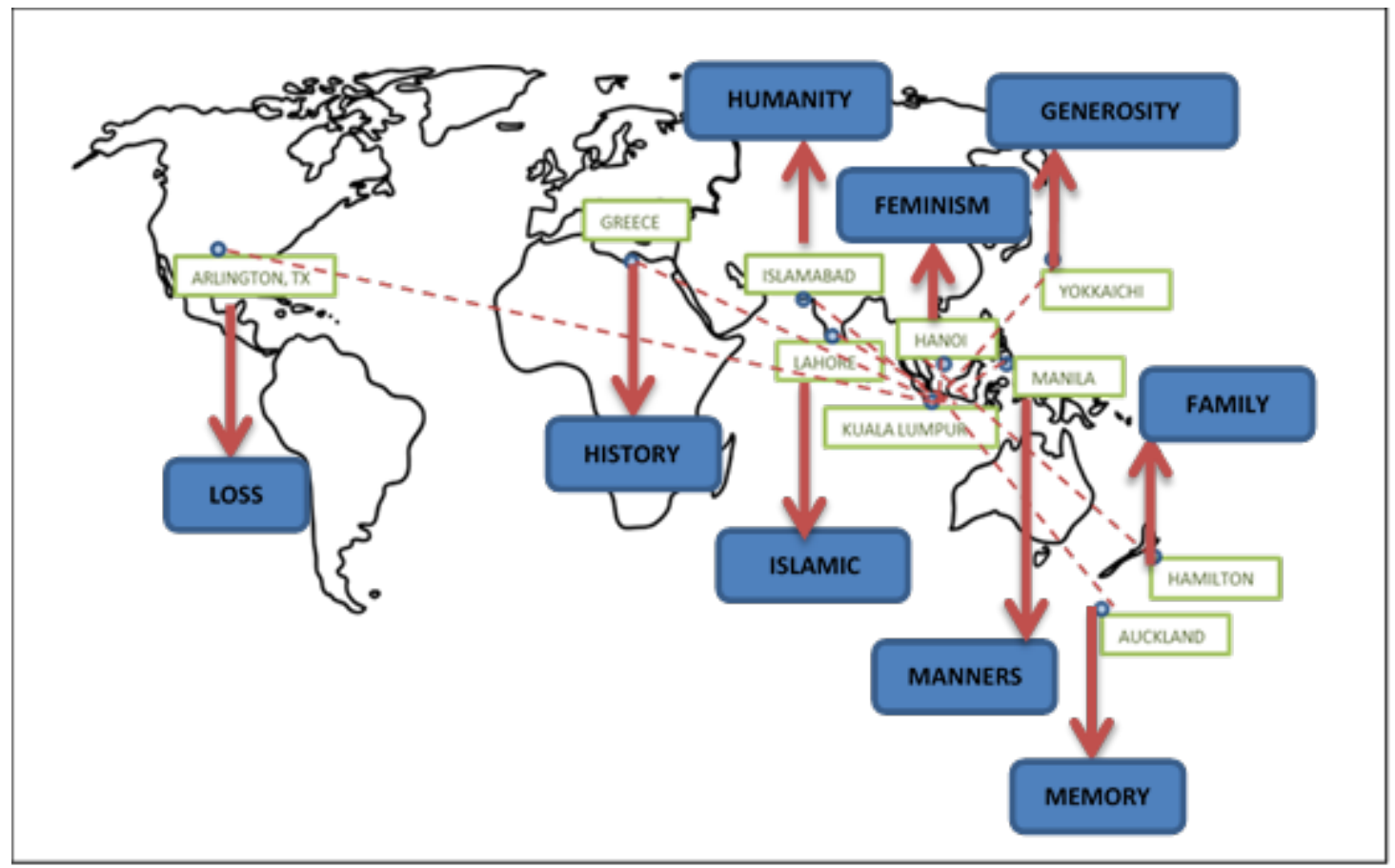

FIGURE 2. The mapping of values learned by Nor Faridah as presented in her poems

The ideals and lessons conveyed in her series of poems are illustrated in Figure 2, have placed Nor Faridah above the normal travellers as she gains more than just the geographical setting of a place as she is able to collect "additional" momentos in terms of valuable lessons from various cities in the world. Faridah's album of poetry, The Art of Naming, is a collection of momentos collected during her journeys. Her experiences are seen as important insights that have influenced and motivated her way of thinking and behaving, whilst broadening her life's perspectives. In addition, her poems are seen as documentations that have the ability to affect her readers as they are provided with facts and lessons garnered from her worthwhile journey. Her role as a flâneur has enabled her to embark on a journey of self-discovery, through which she uses her environmental space to focus on and interpret messages that help her grow as a person.

The findings in this article may be used to reflect on Nor Faridah's trips as a meaningful examination of each location visited, since each location embodies a lesson that she chooses to emphasise both on her journey and as a guide for her readers. The poet has also facilitated the liberty of travellers like her to learn more than what the human eye can see, particularly as a Muslim female traveller, who may face certain conventional preconceptions such as limited mobility and thought. Nor Faridah has not only captured the essence of each location, but has also allowed her voice and perspective to be incorporated into the journey, making it an authentic and empowering step for other female travellers to explore and challenge their perspectives and interpretations of the space and place from a flâneur's point of view, regardless of their religious and cultural differences.

\section{CONCLUSION}

Faridah's travel poetry about various locations around the globe is more than a representation of what the human senses can experience. It transcends human touch and has the ability to manipulate the mind and behaviour in order to effect transformation. This is the experience of a flâneur; an individual who wanders and observes the streets of an urban environment. Although Nor Faridah does not see herself as a flâneur, her works and thematic phrases 
throughout all her poetry speak volumes about the flâneur's role in some of the new and recognisable settings she has visited during her sojourns. According to Susan Sheridan's introduction to the book The Art of Naming, the poems depict "the pleasures of discovery when she goes abroad to fulfil her potential as a scholar" and also "record some poignant moments of connection with others on her travels" (2006, p. xv). The connection described above is only possible if the wanderer chooses to let go of her self-consciousness in order to perceive what her environments have to offer and how they have impacted her.

This article repositions the flâneur's place and work in a way that the person reemerges as a privileged forum for addressing the complex issues inherent in one's surroundings and that the observer receives a second chance to thrive as a strong category of cultural criticism in the present through self-ironic interaction with cultural otherness. As a result, the poems written during her travels are the best representation of Nor Faridah, not only as a travelling flâneur, but also as a means of communicating the positive principles gleaned from her observations of her surroundings to the readers through poetry. Thus, she has embodied Baudelaire's flâneur, who is seen to play a critical role in comprehending, engaging in, and representing the cities visited. Simultaneously, she is the author of each poem's individual city narrative, as she maps these locations in her own planet using experiences learned from her impactful surroundings. This essay serves as a model for future research in the field of psychogeography and literary works since it enables insight into new meanings associated with existential circumstances, resulting in the creation of new literary works overlaid on earlier compositions. Nor Faridah's poetry demonstrates how travelling affected her mentally, emotionally, and physically. This research should imply that future travel is not only about acquiring material possessions but also about gaining and expanding one's inner self in many facets of life.

\section{ACKNOWLEDGEMENT}

This work was supported by the Fundamental Research Grant Scheme (FRGS/1/2014/2/SS102/UKM/01/1), Ministry of Higher Education, Malaysia.

\section{REFERENCES}

Nor Faridah Abdul Manaf. (2006). The Art of Naming: A Muslim Woman's Journey. Subang Jaya: Awards Publishing.

Amir Muhammad. (2001). Silverfish New Writing I. Kuala Lumpur: Silverfishbooks.

Baudelaire, Charles. (1995). The Painter of Modern Life and Other Essays. (P.E. Charvet, Trans.). London: Penguin.

Benjamin, W. (1989). Lyrical Poet in the Advanced Capitalism: Baudelaire. (Zhang Xudong and Wei Wensheng, Trans.). Beijing: SDX Joint Publishing Company.

Bristow, T. (2015). The Anthropocene Lyric: An Affective Geography Of Poetry, Person, Place. New York: Palgrave Macmillan.

Coverley, Merlin. (2006) Psychogeography. Harpenden: Pocket Essentials.

Dean, K. (2018). Virginia Woolf and the flâneuse: A geocritical approach to Mrs. Dalloway and the Voyage Out [Unpublished MA thesis]. University of Nevada.

Debord, G. (2006). Situationist International Anthology. Berkeley: Bureau of Public Secrets.

De Certeau, M. J. E. (1988). The Practices of Everyday Life. Berkeley: University of California Press.

Dreyer, E., \& McDowall, E. (2012). Imagining the flâneur as a woman. Communication Theory and Research. 38(1), 30-44. 
D'Souza, A., \& McDonough, T. (Eds.). (2006). The Invisible Flâneuse?: Gender, Public Space, And Visual Culture In Nineteenth-Century Paris. Manchester: Manchester University Press.

Elkin, L. (2017). Flâneuse: Women Walk the City in Paris, New York, Tokyo, Venice, and London. New York: Farrar, Straus and Giroux.

Ellard, C. (2015). Places Of The Heart: The Psychogeography Of Everyday Life. New York: Bellevue Literary Press.

Friedberg, A. (1993). Window Shopping: Cinema And The Postmodern. California: University of California Press.

Gallagher, M. (2010). The flaneur was here: mobile augmented reality and urban cultural heritage learning in Lower Manhattan. Paper written as part of the MSc in Digital Education at the University of Edinburgh, United Kingdom.

Goebel, R. J. (1998). Benjamin's flâneur in Japan: urban modernity and conceptual relocation. The German Quarterly. 71(4). 377-391.

Hazel Hahn, H. (2012). The flâneur, the tourist, the global flâneur, and magazine reading as flânerie. Dix-Neuf. 16(2), 193-210.

Lynch, Kevin. (1960). The Image of the City. Cambridge, Massachusetts: The Technology Press \& Harvard University Press.

Noraini Md. Yusof. (2003). "Chronicles of the Traveller in Muhammad Haji Salleh's Time and Its People." In Zawiah Yahya (Ed.). Critical Perspectives on Muhammad Haji Salleh. Kuala Lumpur: Dewan Bahasa dan Pustaka.

Nuvolati, G. (2017). Between puer and flâneur. Discovering the city. Ricerche di Pedagogia e Didattica. Journal of Theories and Research in Education. 12(1), 149-163.

Perec, G. (1999). Species of Spaces and Other Pieces. (J. Sturrock. Trans.). London: Penguin. Raihanah, M.M. \& D'Cruz, J. V. (2003). The cosmopolitanism of an early Muhammad Haji Salleh and the quest for a foundational imaginary of home. In Zawiah Yahya (Ed.). Critical Perspectives on Muhammad Haji Salleh (pp. 35-53). Dewan Bahasa dan Pustaka.

Ross, C. (2009). Augmented Reality Art: A Matter of (non)Destination. UC Irvine: Digital Arts and Culture 2009. Retrieved from https://escholarship.org/uc/item/6q71j0zh

Ruzy Suliza Hashim \& Fatin Nur Syahirah Faizal (2017). Psychogeography of Kuala Lumpur in Nassury Ibrahim's selected poems. Malay Literature. 29(2), 165-182.

Snaith, A., \& Whitworth, M. (Eds.). (2007). Locating Woolf: The Politics of Space and Place. Springer.

The World Bank. (2017). Ratio of Female to Male Labor Force Participation Rate (\%). $\begin{array}{llll}\text { Retrieved November } & 1 \text {, } & 2017 & \text { from }\end{array}$ https://data.worldbank.org/indicator/SL.TLF.CACT.FM.ZSlocations=PK

Van Nes, A., \& Nguyen, T. M. (2009). Gender differences in the urban environment: The flâneur and flâneuse of the 21st Century. In Proceedings of the 7th International Space Syntax Symposium. 122, 1-7.

Woolf, V. (2017). Street Haunting: A London Adventure. Read Books Ltd.

Wrigley, R. (Ed.). (2014). The Flâneur Abroad: Historical And International Perspectives. Newcastle upon Tyne: Cambridge Scholars Publishing.

Zawiah Yahya. Ed. (2003). Critical Perspectives on Muhammad Haji Salleh. Kuala Lumpur: Dewan Bahasa dan Pustaka. 


\section{ABOUT THE AUTHORS}

Mohd Fadhli Shah Khaidzir is a lecturer at the School of Education and Social Sciences, Management and Sciences University (MSU). He is currently a Ph.D candidate at the School of Language Studies and Linguistics, Faculty of Social Sciences and Humanities, Universiti Kebangsaan Malaysia.

Ruzy Suliza Hashim (Ph.D) is currently the Director of UKM Press. She is also a Professor of Literature at the School of Language Studies and Linguistics, Faculty of Social Sciences and Humanities, Universiti Kebangsaan Malaysia. Her book Out of the Shadows: Women in Malay Court Narratives won the National Book Award in 2005.

Noraini Md. Yusof (Ph.D) is an Associate Professor and currently the Deputy Director at the Institute of Malaysian and International Studies (IKMAS), Universiti Kebangsaan Malaysia. She is currently the Her areas of interest include history and literature, visual culture as well as creative writing. She has short stories published locally and internationally. 